\title{
An Emerging Human Right to Protection against Unjustified Dismissal
}

\author{
HUGH COLLINS* \\ *London School of Economics. h.collins@1se.ac.uk
}

Key words: Dismissal, Article 8, human right, privacy, unfair dismissal

Abstract: Although a right to protection against unjustified dismissal is not widely recognised in human rights law, the European Court of Human Rights has begun to use Article 8 of the European Convention of Human Rights to develop a general right based on the adverse consequences to ordinary private life caused by an unjustified dismissal. Instead of requiring the employer's reason for the dismissal to be connected to an aspect of an employee's private and family life in order to engage Article 8 , the Court's new, broader approach focuses on major adverse effects or consequences -caused by dismissals to an employee's family life, personal and professional relationships, to self-respect, and to their chosen way of life and career. The consequence-based approach permits the application of Article 8 whatever reason the employer puts forward for the dismissal. The article assesses the extent and limits of the protection against unjustified dismissal under the Convention as a result primarily of this extension from a reasons-based approach to a consequences-based approach to Article 8, an approach that was confirmed by the Grand Chamber in Denisov v Ukraine.

\section{The Missing Right}

Many important rights claimed by workers have been included in influential declarations of human rights. For instance, Article 23 of the Universal Declaration of Human Rights (UDHR) includes among its rights the right to work, the right to just and favourable conditions of work, the right to just and favourable remuneration, and the right to form and join trade unions for the protection of their interests. ${ }^{1}$ The European Convention on Human Rights (ECHR), ${ }^{2}$ as interpreted by the European Court of Human

\footnotetext{
${ }^{1}$ United Nations General Assembly in Paris on 10 December 1948 (General Assembly resolution 217 A).

2 European Convention for the Protection of Human Rights and Fundamental Freedoms as amended by Protocol Nos 11, 1994 ETS 155 and 14, 2010 ETS 194, originally opened for signature 4 November 1950.
} 
Rights (ECtHR) also protects some labour rights, ${ }^{3}$ such as under Article 11 protection of the right to form and join trade unions, to engage in collective bargaining, and subject to limitations, to participate in strike action. ${ }^{4}$ Building on all these statements of rights, it becomes possible to imagine that one might create the foundations for a whole system of labour law through interpretations of human rights law. ${ }^{5}$ Yet this ambition may be thwarted because there is frequently one striking and significant omission from these declarations of labour rights as human rights. There is rarely any explicit mention of any substantive human right to protection against unjustified, unlawful, or unfair dismissal. ${ }^{6}$

Explicit mention of a fundamental right to protection against unjustified dismissal is absent from the Declaration of Philadelphia of the International Labour Organisation (ILO) in $1944,^{7}$ the Universal Declaration of Human Rights 1948, and the International Covenant on Economic Social and Cultural Rights 1966. ${ }^{8}$ The ILO's Declaration on Fundamental Principles and Rights at Work in 1998 also makes no mention of a general right to protection against unjustified dismissal. ${ }^{9}$ The right was not part of the original package of core ILO Conventions, though following an earlier recommendation in 1982, the ILO eventually agreed a Convention that sets out important standards for laws giving protection against unjustified dismissal (in the sense of termination without a valid reason). ${ }^{10}$ The

\footnotetext{
3 V Mantouvalou, 'Are Labour Rights Human Rights?' (2012) 3 European Labour Law Journal 151.

${ }^{4}$ Demir \& Baykara v Turkey (app no 34503/97) [2009] IRLR 766 (Grand Chamber, ECtHR).

5 J Atkinson, 'Human Rights as Foundations for Labour Law' in H Collins, G Lester, and V Mantouvalou (eds), Philosophical Foundations of Labour Law (Oxford University Press, 2018) 122.

${ }^{6}$ In this article, an international human right will be described as a right to protection against unjustified dismissal, terminology that is close to that used by the ILO and the Council of Europe. The term 'unfair dismissal' will normally be reserved for the domestic law of the United Kingdom found in the Employment Rights Act 1996 Part X.

${ }^{7}$ Declaration concerning the aims and purposes of the International Labour Organisation (Declaration of Philadelphia) May 1944, appended to the constitution of the ILO.

${ }^{8}$ Adopted and opened for signature, ratification and accession by General Assembly resolution 2200A (XXI) of 16 December 1966; entry into force 3 January 1976, in accordance with Article 27. UN Committee on Economic, Social and Cultural Rights has, however, in General Comment No.18 on the Right to Work expressed the view that a failure of States 'to protect workers against unlawful dismissal' would be a violation of the right to work: (E/C.12/GC/18) 24 November 2005, at para 35.

${ }^{9}$ ILO Declaration on Fundamental Principles and Rights at Work and its Follow-up, Adopted by the International Labour Conference at its Eighty-sixth Session, Geneva, 18 June 1998.

${ }^{10}$ ILO, Termination of Employment Recommendation 1963, (No.119); ILO, Convention No. 158 concerning Termination of Employment at the Initiative of the Employer (1982). The ILO standard is not described as a right but rather proposes the rule that employment should not be terminated without a valid reason. The Convention has only been ratified by 36 states, which do not include most of the major economic powers. Nevertheless, the Convention has been influential and many states that have not ratified the Convention (including the UK) have enacted comparable standards. More detail about the interpretation of and the implications of the Convention is provided by the Termination of Employment Recommendation, 1982 (No. 166) (R166).
} 
tardiness of the acceptance of this right in a Convention is probably explicable by the opposition from employers' representatives within the ILO to the recognition of and the strengthening of a right to protection against unjustified dismissal. ${ }^{11}$

The right was also missing from the original European Social Charter of 1961. But under the influence of the ILO Convention, ${ }^{12}$ a provision was included in Article 24 of the Council of Europe's Revised European Social Charter of 1996, which proclaims 'the right of all workers not to have their employment terminated without valid reasons'. Article 24 was the first declaration of an international fundamental right to protection against unjust dismissal. Although the Revised European Social Charter is not judicially enforceable and indeed has not even been ratified by the UK, the declaration of the right may have influenced the legal reasoning of some courts such as the ECtHR, ${ }^{13}$ and can form the basis for some signatory countries to utilise under the collective complaints procedure of the Charter. ${ }^{14}$

As regards a fundamental right with some indirect legal effect in the UK, it is only Article 30 of the Charter of Fundamental Rights of the European Union that explicitly mentions a worker's right to protection against unjustified dismissal: 'Every worker has the right to protection against unjustified dismissal, in accordance with Union law and national laws and practices'. ${ }^{15}$ The limitation of the right to existing laws in the EU and member states, however, appears to prevent it from having any direct effect of its own. ${ }^{16}$ Furthermore, in this field of dismissal, the Charter is unlikely to have a significant

\footnotetext{
${ }^{11}$ See for instance the opposition of employers' representatives to any strengthening of the ILO regime: International Labour Organization, International Labour Standards Department, Final report Tripartite Meeting of Experts to Examine the Termination of Employment Convention, 1982 (No. 158), and the Termination of Employment Recommendation, 1982 (No. 166) (Geneva, 18-21 April 2011).

12 M Schmitt, 'Article 24 The Right to Protection in Cases of Termination of Employment' in N Bruun, K Lorcher, I Schomann, and S Clauwaert (eds) The European Social Charter and the Employment Relation (Hart Publishing, Oxford, 2017) 412, 415.

${ }^{13}$ See K.M.C. v Hungary (App no 19554/11), discussed below at n 108.

${ }^{14}$ Additional Protocol to the European Social Charter providing for a system of collective complaints, eg the unsuccessful complaint in Finnish Society of Social Rights v Finland, Complaint No. 107/2014, CM(2016)164. 15 2012/C 326/02.

${ }^{16}$ ETF v Schuerings, T-107/11 P, EU:T:2013:624, para 100 ' Article 30 of the [C]harter ... does not lay down any specific obligations.' D Leczykiewicz, 'Effectiveness of EU Law Before National Courts: Direct Effect, Effective Judicial Protection, and State Liability' in A Arnull and D Chalmers (eds), Oxford Handbook of European Union Law (Oxford University Press 2015) 212.
} 
indirect impact through interpretation because it only applies when Union law is being implemented, ${ }^{17}$ and there are only a few EU measures that concern dismissal. ${ }^{18}$

Nevertheless, the missing protection against unjustified dismissal as a fundamental right with legal force has been partly addressed by recent decisions of the ECtHR under the ECHR. This protection has legal force both by virtue of the possibility of individual applications to the ECtHR claiming violation of rights and, in the UK, by virtue of the Human Rights Act 1998. The Act is likely to be applicable to cases of dismissal as a result of the obligation under section 3 to interpret national legislation in conformity with Convention rights. ${ }^{19}$ For several decades the ECtHR has frequently demonstrated a willingness to apply Convention rights to the context of dismissal. For instance, in Vogt $v$ Germany, ${ }^{20}$ the Court found a violation of freedom of expression in Article 10 for the dismissal of a schoolteacher for her political views expressed outside work. The ECtHR also developed a positive duty placed on contracting states to create laws that protect workers in the private sector against dismissals that interfered unjustifiably with their Convention rights, as in the case of James, Young, and Webster $v$ United Kingdom concerning the closed shop and freedom of association. ${ }^{21}$ Until recently, however, to succeed in an application before the ECtHR, a worker had to demonstrate that the employer's reason for a dismissal or other disciplinary action involved a direct interference with a particular right under the Convention, such as a denial of respect for private life under Article 8 in cases of dismissal for sexual orientation, ${ }^{22}$ or a manifestation of a religion under Article $9,{ }^{23}$ or the exercise of freedom of expression in the case of whistle-blowers, ${ }^{24}$ or interference with the right to be a member of a political party under the right to freedom of association. ${ }^{25}$ Hitherto, these findings of an unlawful

\footnotetext{
${ }^{17}$ Article 51 Charter of the Fundamental rights of the EU; EU law is mostly concerned with dismissals for business reasons so is unlikely to apply to dismissals for disciplinary reasons: Joined Cases C-488/12, C-489/12, C-490/12, C-491/12 and C-526/12 Nagy and others v Hajdú-Bihar Megyei Kormányhivatal ECLI:EU:C:2013: 703.

${ }^{18}$ Eg Directive 98/59/EC on the approximation of the laws relating to collective redundancies; Directive $2001 / 23$ EC on the approximation of the laws relating to the safeguarding of employees' rights in the event of transfers of undertakings.

${ }^{19}$ P Collins, 'The Inadequate Protection of Human Rights in Unfair Dismissal Law' (2018) 47 ILJ 504.

20 Vogt $v$ Germany (1996) 21 EHRR 2015.

21 Young, James, and Webster v United Kingdom (1982) 4 EHRR 38.

22 Smith and Grady $v$ United Kingdom [1999] ECHR 72.

${ }^{23}$ Eg Ewieda $v$ UK [2013] ECHR 37.

${ }^{24} \mathrm{E}, \mathrm{g}$, Heinisch v Germany [2011] ECHR 1175.

${ }^{25}$ Redfearn v UK [2012] ECHR 1878.
} 
dismissal in contravention of the Convention have relied on a reason-based approach: the injustice stems from the employer's reason for dismissal involving an unjustified interference with a protected Convention right.

What has changed recently is that the ECtHR now permits a much broader scope for challenging unjustified dismissals. Instead of examining the employer's reason for dismissal to assess whether it falls within the scope of a Convention right, the ECtHR now permits the adverse effects or consequences of a dismissal for an employee's personal life to bring a case within the scope of Article 8 ECHR. The ECtHR has held that dismissals from a job may have severely deleterious consequences for a worker's private life, not only in material terms of causing poverty and economic insecurity, but also in psychological terms of ruining a person's hopes of a career, expectations of fulfilment through work, undermining personal relationships at home and at, work, and obstructing life plans in general. What is important to notice is that these destabilising adverse consequences to private life may arise whatever the employer's reason for making a dismissal. There may be devastating consequences for an employee's personal life whether the dismissal is justified by the employer on grounds of misconduct, incompetence, redundancy, financial exigency, or any kinds of capricious or arbitrary grounds, including giving no reason at all. If serious adverse consequences to a worker's personal life are caused by a dismissal, whatever the reason for the dismissal, Article 8 is likely to be engaged. The potential scope of the regulation of dismissals by the ECHR is therefore greatly expanded from the 'reasonsbased' approach that prevailed in the past to a broader 'consequences-based' approach that may include dismissals for any kind of reason. In September 2018, in Denisov v Ukraine, ${ }^{26}$ the Grand Chamber of the ECtHR confirmed unanimously that where a dismissal or other disciplinary action by an employer has severe consequences on a person's ordinary private life, in order to comply with the right to respect for private life in Article 8 ECHR, national law must require the employer to justify the dismissal under a test of proportionality in accordance with Article 8(2). Under the positive duties placed on contracting states by the Convention, national laws must be adjusted to conform to Article 8 by providing the worker with an adequate legal remedy against the unjustified dismissal.

${ }^{26}$ Denisov v Ukraine [2018] ECHR 1061. 
The principal purpose of this Article is to assess the scope and implications of this consequencebased interpretation of Article 8 ECHR to provide the basis for the first time of a legally binding international protection of a fundamental or human right to protection against unjustified dismissal. This creation of a fundamental right to protection against dismissal by the ECtHR seems likely to exercise a strong gravitational force on national labour law systems, both because the right provides a fundamental protection for workers in many contexts of employment disputes and because it is not as severely limited by deference by the ECHR to national legal orders as has been the case in other contexts such as strikes. ${ }^{27}$

The next section of this Article briefly reviews the arguments for regarding a right to protection against unjustified dismissal as a fundamental right of workers and one that should be dignified by the label of being a human right. The third section describes and analyses the recent decisions of the ECtHR that have adopted a broader, consequence-based, approach to protection against unjustified dismissal through the mechanism of Article 8 ECHR. In order to understand the precise scope of this expanded protection against unjustified dismissal, the fourth section analyses what kinds of harms to private and family life are likely to be regarded by the ECtHR as sufficient to amount to an interference with Article 8. The answer to that question depends on a deeper understanding of the Court's conception of privacy, which has evolved to include a right to personal development. A final section briefly examines the potential limits on the scope of protection against unjustified dismissal afforded by a fundamental right based on Article 8 ECHR. The conclusion reflects briefly on what impact the recognition of such a human right to protection against unjustified dismissal may eventually have on national legal orders such as the law of unfair dismissal in the UK.

\section{The Moral Foundations of a Human Right against Unjustified Dismissal}

Why should a right to protection against unjustified dismissal be regarded as a human right? Its absence from the most influential statements of human rights and fundamental labour rights and its relatively

\footnotetext{
${ }^{27}$ National Union of Rail, Maritime and Transport Workers $v$ United Kingdom (App.no.31045/10) [2014] ECHR 366, [2014] IRLR 467; A Bogg and K Ewing, 'The Implications of the RMT Case' (2014) 43 ILJ 221.
} 
recent emergence in some statements of social and economic rights appear to cast doubt on its qualifications to be regarded as a fundamental human right. Yet the case for classifying it as a human right is surely at least as strong as the reasons for including the rights already recognised, such as those in Article 23 UDHR.

The case for recognising any labour rights as human rights ultimately depends, I suggest, on the recognition that workers need a special set of protections in order to avoid having both their dignity and respect for their autonomy undermined. There are strong tendencies in a market society for workers to be treated much like things or machines, for employers need to extract their labour power as efficiently as possible. A principal goal of labour law, often expressed in the maxim 'labour is not a commodity, ${ }^{28}$ is to resist that tendency towards reducing labour to a mere commodity or machine. If workers are so treated, they are likely to be deprived of their dignity and to have their autonomy unjustifiably restricted. Key measures against the commodification of labour have been included in Conventions such as the UDHR because they lay down the seeds of a protective legal framework for workers. Limits on working hours and family friendly policies recognise, for instance, that workers should be treated as human beings, with their own lives and families to maintain. Similarly, protection against unjustified dismissal both protects against denials of dignity to the worker and also safeguards the autonomy of the individual worker against unjustified interference. ${ }^{29}$

An unjustified dismissal is often a moment when employees are treated with little or no dignity. For reasons of efficiency, employers need to be able to back up their management of the workforce with disciplinary sanctions for disobedience or failures to perform the work. But those efficiency considerations do not require employers to have an arbitrary power to terminate contracts of employment at will for any reason or no reason at all. It should not significantly detract from the effectiveness of management if the disciplinary power can only lawfully be exercised for a legitimate purpose and in a fair manner. When disciplinary powers are abused or misused, however, a dismissal without an adequate and legitimate reason will in effect deny respect to an employee. Summary

\footnotetext{
28 Originally formulated as an international labour standard in the Treaty of Versailles (Treaty of Peace with Germany) 28 June 1919, Article 427 General Principles, First; P O'Higgins, "'Labour is not a Commodity" - an Irish Contribution to International Labour Law' (1997) 26 Industrial Law Journal 225, 229.

${ }^{29}$ H Collins, Justice in Dismissal (Oxford: Oxford University Press, 1992) 15-21.
} 
dismissal can be a humiliating experience that may make an employee feel worthless. If it is suspected that the reasons for the dismissal include factors such as sex and race, these aggravating factors will add to the disrespect signified by the dismissal and quite likely undermine a person's self-esteem. Similarly, where the reasons for dismissal are believed to be false or capricious, there is an inherent denial of respect for the employee. Firing workers at the will of the employer, for unfair reasons, capricious reasons, or no reasons at all epitomises the treatment of workers as a commodity or a tool. The worker is treated like a machine, disconnected when no longer required.

At the same time, protection against unjustified dismissal serves to protect the autonomy of the individual worker. The value of autonomy is understood here to mean the opportunity for individuals to control and develop their own lives. As Joseph Raz argues, a liberal society should foster worthwhile opportunities for people to pursue their personal goals in order to augment their autonomy. ${ }^{30}$ For many people, the opportunities afforded by their job are significant and manifold. Most people find some meaning for their lives through work. As philosophers from Aristotle to Hegel and Marx have revealed, the mental and physical challenges of work provide a focal point of meaning for one's life. ${ }^{31}$ At the same time, work provides opportunities for social interaction, networking, making friends, and even falling in love. These links between the value of autonomy and work can also be expressed by reference to a right to work. $^{32}$ In order to enjoy autonomy, it is likely that people will seek fairly stable employment. Precarious jobs undermine workers' autonomy by blocking any opportunities to plan for their lives. Equally, working under the risk of termination at the employer's unfettered discretion without the need to establish sound reasons for dismissal systematically undermines the opportunity to be an author of one's own life. Protection against unjustified dismissal from a job reduces that risk of the autonomy of individuals being undermined by the persistent implicit threat of peremptory termination of employment.

\footnotetext{
30 J. Raz, The Morality of Freedom (Oxford: Oxford University Press, 1986).

${ }^{31}$ D Wiggins, 'Work, its Moral Meaning or Import' in V. Mantouvalou (ed), The Right to Work (Oxford: Hart Publishing, 2015) 11.

${ }^{32}$ Cf General Comment, above n 8; H. Collins, 'Is There a Human Right to Work?' in V. Mantouvalou (ed), The Right to Work (Oxford: Hart Publishing, 2015) 17.
} 
A right to protection against unjustified dismissal therefore serves a similar purpose to those labour rights that have been acknowledged as human rights. It protects the values of dignity and autonomy that not only lie at the heart of justifications for labour law, but also, of course, values that provide one of the most important moral justifications for the very concept of human rights. ${ }^{33}$ The strongest case for creating a human right against unjustified dismissal is that it provides a core ingredient in the humanitarian project proclaimed at the end of both world wars (in the Treaty of Versailles 1919 and the Declaration of Philadelphia 1944) to ensure that workers are treated like human beings rather than machines. That humanitarian project gave birth to the idea of human rights of which an important part was to ensure that workers were not treated like commodities, but rather with dignity and respect for their autonomy.

\section{The Consequence-based approach to Article 8}

How has Article 8 ECHR been used to generate elements of a general protection against unjustified dismissal? Article 8(1) states: 'Everyone has the right to respect for his private and family life, his home and his correspondence.' Article 8(2) permits exceptions provided they are authorised by law and are proportionate measures for the protection of rights of others or some other legitimate aim. ${ }^{34}$ At first sight, it is not evident why a dismissal from a job may count as an interference with the enjoyment of this right to respect for private life. The constitutional right to privacy is often summed up as 'a right to be left alone', ${ }^{35}$ or a right to be protected against intrusions into one's home and personal life. ${ }^{36}$ The right to privacy has, for instance, provided the foundation for the protection of freedom of sexual orientation from state interference and intrusion. ${ }^{37}$ In contrast, dismissal from a job is likely to be a

\footnotetext{
${ }^{33}$ A pluralist account using both these values and others seems to be most plausible account of the idea of human rights: J Tasioulas, 'Towards a Philosophy of Human Rights' (2012) 65 Current Legal Problems 1.

${ }^{34}$ Article 8(2): 'There shall be no interference by a public authority with the exercise of this right except such as is in accordance with the law and is necessary in a democratic society in the interests of national security, public safety or the economic well-being of the country, for the prevention of disorder or crime, for the protection of health or morals, or for the protection of the rights and freedoms of others.'

${ }^{35}$ S. Warren and L. Brandeis, 'The Right to Privacy' (1890) 4 Harvard Law Review 193.

36 A. Westin, Privacy and Freedom (New York; Atheneum Press, 1970).

${ }^{37}$ Lawrence v Texas (2003) 539 US 558; Dudgeon v United Kingdom (1981) 4 EHRR 149.
} 
relatively public event in the workplace. Moreover, dismissal concerns primarily economic or contractual relations rather than personal life in the home or intimate family relations. Ironically, insofar as the idea of privacy has been linked to dismissal in the past, it was used as a reason put forward by employers for rejecting any interference by the state in the way they govern their businesses; with support from the common law courts, masters claimed to be entitled to rule their own households, including the discipline of family and servants, without interference by the state. ${ }^{38}$ To use Article 8 as the source for a general right to protection against unjustified dismissal therefore requires a revised conception of privacy that explains and justifies its application in this context.

For several decades, Article 8 has been used by the ECtHR according to its more traditional meanings in particular instances of dismissal. It can apply to dismissals or disciplinary actions that involve unjustified interception of communications and correspondence. ${ }^{39}$ It protects an individual's control over the information that is known about him or her, as in the case of drug testing, ${ }^{40}$ or an employer's secret use of CCTV cameras in the workplace. ${ }^{41}$ Article 8 is also used to protect those aspects of privacy that concern the peaceful enjoyment of family relations, living in one's home without disturbance by others, and the privacy of sexual and intimate relations. ${ }^{42}$ But these specific uses of Article 8 in cases of discipline and dismissal at work are not examples of the broader, consequencebased use to which it is now put in a wide range of dismissals and which are the focus of the discussion here. This consequence-based interpretation of Article 8 slowly emerged through a line of cases that should now be considered. The route towards the final outcome of a general protection against unjustified dismissal involves some productive mis-readings of earlier cases and closely fought disagreements in the Grand Chamber that perhaps resulted in some unforeseen legal consequences.

\footnotetext{
38 Payne v Western \& Atl.R.R. 81 Tenn.507 (1884) 'Men must be left without interference... to discharge or retain employees at will for good cause or for no cause, or even for bad cause without thereby being guilty of an unlawful act per se'. See Matthew W Finkin, 'Employee Privacy, American Values, and the Law' (1996) 72 Chicago-Kent Law Review 221, 254 on the 'Whig Tradition';

${ }^{39}$ Halford v UK (1997) 24 EHRR 523; Copland v United Kingdom [2017] ECHR 253; Bărbulescu v Romania [2016] IRLR 235, [2016] ECHR 61.

40 Madsen v Denmark [2002] ECHR 855; cf A. Westin, Privacy and Freedom (New York: Atheneum, 1967) 7.

${ }^{41}$ Kopke v Germany [2010] ECHR 1725.

${ }^{42}$ Lustig-Prean and Beckett $v$ United Kingdom (1999) 29 EHRR 548. Pay v UK [2009] IRLR 139 [2008] ECHR 1007; V Mantouvalou, Human Rights and Unfair Dismissal: Private Acts in Public Spaces' (2008) 71 Modern Law Review 912.
} 
The first sign of this broader use of Article 8 by the ECtHR arose in Sidabras and Džiautas $v$ Lithuania. ${ }^{43}$ The applicants had been dismissed from their public sector jobs in accordance with a new law that prohibited the employment of 'former KGB officers' not only in the public sector but also in law firms, banks, communications organisations, and educational institutions. The ECtHR decided the case on the narrow and slightly unclear ground that combined Article 8 with Article 14, the provision that requires all the Convention rights to be protected and applied without discrimination. The Court held that the prevention of the applicants from obtaining a wide and indeterminate range of private sector jobs fell 'within the ambit' of Article 8, and though the legislation pursued the legitimate aim of national security, it was a disproportionate discriminatory measure against former officers in the security services, contrary to Article 14 read in conjunction with Article 8. The reliance on Article 14 as opposed to using Article 8 alone is puzzling. ${ }^{44}$ Perhaps the majority of the court was concerned that the case was unduly stretching the meaning of Article 8 by the adoption of a consequence-based approach. After all, the impugned Lithuanian law did not directly interfere in the applicants' homes or private lives; rather it was their exclusion from large swathes of the labour market that damaged their personal lives. As the Court observed, the ban on seeking employment affected to an extremely significant degree the opportunities for the applicants to pursue various professional activities and that, as a consequence, they were prevented from 'leading a normal personal life'. ${ }^{45}$ Having attached particular weight to the right to work in Article 1 of the European Social Charter 1961, as interpreted to apply to discrimination in employment by the European Committee of Social Rights, ${ }^{46}$ the ECtHR held that the interference with Article 8 consisted of the adverse effects on 'the applicants' ability to develop relationships with the outside world to a very significant degree' and the creation of serious difficulties in earning a living. ${ }^{47}$ With benefit of hindsight, the crucial development in this case was that it was the adverse consequences for a normal private life caused by a dismissal and exclusion from large parts of the labour market that justified the application of Article 8. The grounding of the decision

\footnotetext{
43 Sidabras and Džiautas v Lithuania [2004] ECHR 395.

44 V Mantouvalou, 'Work and Private Life: Sidabras and Džiautas v Lithuania (2005) 30 European Law Review 573.

45 Sidabras n 43 above [49].

46 Sidabras $n 43$ above [31].

47 Sidabras n 43 above [48].
} 
on Article 14 may perhaps be explained by the unfamiliarity of a consequence-based approach to Article 8.

This assessment of the consequences for private life of a dismissal was applied again in Özpinar v. Turkey. ${ }^{48}$ The applicant was a judge living in Ankara. A secret disciplinary procedure was opened against her in response to an anonymous complaint 'on behalf of a group of patriotic police officers'. Following an investigation, the public prosecutor alleged that she had a close relationship with a male lawyer whose clients allegedly benefitted from her favourable decisions, that she was repeatedly late for work, that she wore unsuitable clothing such as a miniskirt and make-up, and that she lived as a single woman apart from her parents. Apparently accepting these allegations, the National Legal Service Council removed her from office on the grounds that by her inappropriate attitudes and relationships' she had 'undermined the dignity and honour of the profession'. On learning of her dismissal, she asked the Council for a reconsideration, but at a re-hearing she was not given advance notice of the detailed allegations and evidence against her, and the dismissal was confirmed by the Council, though without giving reasons. She denied all the allegations against her except that she lived alone and occasionally male lawyers attended meetings in her office. The ECtHR noted that the reasons for her dismissal concerned both her private life and her professional life in the performance of the job, but that in fact the investigation had not substantiated the allegations about her poor and corrupt performance of the job, which only left her conduct in her private life as a ground for dismissal. The dismissal had also damaged her reputation, which is also protected by Article 8. When the Court considered the question of whether the interference could be justified as a proportionate measure under Article $8(2)$, it accepted that protection of the integrity of the judiciary was a legitimate aim for interfering with judges' private life, but concluded that the interference with the applicant's private life had not been proportionate. The ECtHR insisted that a judge should not be dismissed on grounds related to private life without a guarantee of adversarial proceedings before an independent and impartial supervisory body. Such a guarantee was especially important because her dismissal also automatically removed her right to practice law. In this case, the ECtHR seems to have concluded that Article 8 was

48 Özpınar v. Turkey, app no. 20999/04 §§ 43-48, 19 October 2010. 
engaged because the reason for her dismissal boiled down to criticisms based on unsubstantiated rumours about her private life. The severe consequences of the dismissal for her private life, both the damage to her reputation and her exclusion from the legal profession entirely, were used as reasons for declaring the dismissal a disproportionate measure under Article 8(2). That approach to using the consequences of the dismissal as part of the test of proportionality was already well established, as in cases such as the admissibility decision in Pay $v U K$, where it was said 'The Court notes at the outset that the dismissal of a specialist public servant...is a very severe measure, because of the effects on his reputation and on his chances of exercising the profession for which he has been trained and acquired skills and experience...,49

Nevertheless, Özpinar v. Turkey was subsequently used in Oleksandr Volkov v Ukraine to support the broader proposition that 'dismissal from office has been found to interfere with the right to respect for private life, ${ }^{50}$ In Oleksandr Volkov, the dismissal of a judge on the grounds of an alleged violation of his professional duties amounting to a breach of the judicial oath was found to have interfered with his private life under Article 8 . The ECtHR brought the case under Article 8 by pointing to a broad range of adverse consequences of the dismissal for the ordinary private life of the applicant.

'The dismissal of the applicant from the post of judge affected a wide range of his relationships with other persons, including relationships of a professional nature. Likewise, it had an impact on his "inner circle" as the loss of his job must have had tangible consequences for the material well-being of the applicant and his family. Moreover, the reason for the applicant's dismissal, namely breach of the judicial oath, suggests that his professional reputation was affected. ${ }^{51}$ Many dismissals of people in any line of work might have similar adverse consequences for a person's private life. This ground for the application of Article 8 therefore opened up the possibility of a broad protection against unjustified dismissal on the basis of a consequences-based approach. It is perhaps worth noting that in Oleksandr Volkov the application of Article 8 to professional misconduct was uncontested by the Ukrainian government, so it was not examined in any detail by the Court. It was

\footnotetext{
${ }^{49}$ Pay above n 42.

50 Oleksandr Volkov v Ukraine [2011] ECHR 1871 [165].

51 Ibid [166].
} 
also unnecessary to consider the issue of proportionality because the ECtHR concluded that the dismissal had not been in accordance with domestic law. The result was that the consequence-based approach could be applied to dismissals without the need for conjunction with Article 14 to bring a case within Article 8. Furthermore, the consequence-based approach was used to interpret Article 8(1) rather than merely being used in the assessment of proportionality, as in Özpinar v. Turkey and Pay v United Kingdom.

The proposition that dismissal from office of a civil servant constitutes an interference with the right to private life was repeated in Emel Boyraz $v$ Turkey. ${ }^{52}$ The female applicant was dismissed from her position as a security guard for TEDAS, the state-run electricity company, on the ground that the post in question was reserved for those who had done military service, a condition that could only be satisfied by men. In a case that was presented under Article 14 together with Article 8, the ECtHR concluded that it fell within the ambit of Article 8 for several reasons.

'[D]ismissal from a post on the sole ground of sex has adverse effect on a person's identity, self-perception and self-respect and, as a result, his or her private life...Besides, the applicant's dismissal had an impact on her 'inner circle' as the loss of her job must have had tangible consequences for the material well-being of her and her family...The applicant must also have suffered distress and anxiety on account of the loss of her post. What is more, the applicant's dismissal affected a wide range of her relationships with other people, including those of a professional nature and her ability to practice a profession which corresponded to her qualifications... ${ }^{53}$

Although the reasons given for attaching this case to Article 8 perhaps commence with matters that are linked to private life, such as a person's gender or identity, the other grounds such as loss of professional and personal contacts, material and psychological adverse effects, and exclusion from a chosen profession look rather to the consequences of a dismissal on a person's ordinary life. The ECtHR concluded that the difference in treatment between men and women did not pursue a legitimate aim, so there was a violation of Article 14 taken in conjunction with Article 8.

\footnotetext{
52 Emel Boyraz v Turkey [2014] ECHR 1344, [2015] IRLR 164 [43].

53 Ibid [44].
} 
A similar blend of reasons that were connected to the traditional conception of privacy and those concerned mainly with the consequences for a person's life is found in the decision of the Grand Chamber ECtHR in Fernández Martinez v Spain. ${ }^{54}$ The applicant, a Catholic priest, applied for a papal dispensation from celibacy, but on hearing nothing, after a year, he married and subsequently had five children. Many years later he obtained a fixed term, but renewable, job of teaching religious education in schools. Spanish law provided that although the state employed the teacher, it should only appoint those persons who had been given prior approval by the Church authorities to be teachers of religious education. Several years later, a newspaper carried a story about a gathering of married priests and their families, which included a picture of the applicant with his family and an interview in which the applicant had explained why priests should be permitted to marry. It was surely no coincidence that a few months later the pope finally granted his request for dispensation from celibacy, but also withdrew his status as a priest. Probably concerned about the publicity given to the scandal of married priests, the local bishop removed his certification of the applicant as a person qualified to teach religion, and the state subsequently did not renew his contract of employment in accordance with domestic law. The applicant's claim for unfair dismissal under Spanish law was unsuccessful owing to his lack of the requisite approval by the Church.

The majority of the ECtHR held that Article 8 was applicable because the dismissal and exclusion from the applicant's professional life as a teacher of religious education at age 60 were serious consequences that occurred on account of events mainly relating to personal choices he had made in his private and family life. ${ }^{55}$ This basis for the application of Article 8 blends a consequence-based approach that emphasises the applicant's permanent exclusion from a chosen profession with a reasonsbased approach that links the motive for the dismissal to his private life in the traditional sense of family life. The minority preferred to stick to the traditional reason-based approach that Article 8 applied the dismissal was a response to the way in which he manifested his private and family life. ${ }^{56}$ The Court proceeded to consider the adequacy of the justification for this interference in the pursuit of the

\footnotetext{
${ }^{54}$ Fernández Martinez v Spain, (App no 56030/07) [2014] ECHR 615.

${ }^{55}$ Ibid [113].

${ }^{56}$ Ibid, dissent, [10].
} 
legitimate goal of respecting the autonomy of the Catholic Church in respect of its choice of persons accredited to teach religious doctrine. The majority of the Court concluded that in upholding the fairness of the dismissal, the Spanish courts had acted within the margin of appreciation for making the judgment about the proportionality of the dismissal. ${ }^{57}$ The minority argued to the contrary that the dismissal was disproportionate, stressing in particular the adverse consequences resulting from dismissal of unemployment and exclusion from his profession. ${ }^{58}$ Notice how the majority used the consequencebased approach to expand the concept of private life, whereas the minority adopted the earlier approach of only considering consequences when the issue of justification under Article 8(2) was addressed.

All the above cases involved public sector officials and employees, but similar approaches had emerged with regard to private sector employees. In Schüth v Germany, ${ }^{59}$ an organist in a Catholic Church was dismissed for having an extra-marital affair that the Church regarded as a breach of a contractual requirement to observe the Church's principles. His claim for unfair dismissal was unsuccessful in the German labour courts. The ECtHR concluded, however, that the state had failed to provide adequate protection for the applicant's right under Article 8, because the national courts had not attached sufficient weight to the point that the applicant would never be able to work as a Church organist in Germany again. This consequence-based aspect of the application of Article 8 seems to have been regarded as relevant both to the scope of the concept of privacy and the issue of proportionality.

A consequence-based approach was also applied in the private sector case of $I B v$ Greece. ${ }^{60}$ The applicant had been dismissed from his job in a jewellery manufacturer when his colleagues learned that he was HIV positive and out of unjustified fear threatened to disrupt the business unless the applicant was dismissed. The claim was framed under Article 14 taken in conjunction with Article 8 . Using a consequence-based approach, the ECtHR held that the case fell within the ambit of Article 8 because the dismissal 'was bound to have serious repercussions for his personality rights, the respect owed to him and, ultimately, his private life....The fact that the applicant did find a new job after being

\footnotetext{
57 Ibid [151].

58 Ibid, dissent, [36-37].

59 Schüth v Germany (App no 1620/03).

${ }^{60}$ I B v Greece (App no 552/10) (Judgment 3 Oct 2013).
} 
dismissed does not suffice to erase the detrimental effect of his dismissal on his ability to lead a normal personal life. ${ }^{61}$ On the question of whether the dismissal might nevertheless be justified, the ECtHR held that the Greek Court of Cassation had not adequately explained why the employer's interests in avoiding disruption should prevail, so the applicant had been discriminated against on the ground of his health, in breach of Article 14 taken in conjunction with Article 8.

These decisions and others regarding the application of Article 8 to dismissals based in whole or in part on the adverse consequences for a person's ordinary private life culminated in the Grand Chamber's decision in Denisov v Ukraine. ${ }^{62}$ In this case, after a long and distinguished career as a judge, while the applicant was taking a long summer holiday, he was removed from his office of president of a Court of Appeal (though he retained his office as a judge) on the ground of 'significant shortcomings, omissions and errors, and grave violation of the foundation of the organisation and administration of justice.' The application to the ECtHR succeeded under Article 6, because the applicant had not had the opportunity to challenge his removal from office before an independent and impartial tribunal. When considering the application of Article 8(1) to the dismissal, the Court approved and applied a consequence-based approach, making it clear from its analysis of prior decisions and the general principles to be drawn from them that the adverse effects of a dismissal on personal life provide an independent ground for invoking Article 8. In particular, the Court referred to three kinds of possible adverse consequences that might justify the application of Article 8(1): '(i) impact on the individual's "inner circle", in particular where there are serious material consequences; (ii) the individual's opportunities "to establish and develop relationships with others", and (iii) the impact on the individual's reputation'. ${ }^{63}$ The Court then added, however, a crucial proviso that had not been stressed as much before. 'In cases where the Court employs the consequence-based approach, the analysis of the seriousness of the impugned measure's effects occupies an important place. ${ }^{64}$ In this case, the applicant was unable to show sufficient evidence of seriously harmful matters such as significant loss

\footnotetext{
61 Ibid [72]

${ }^{62}$ Denisov v Ukraine above n 26.

63 Ibid [107].

64 Ibid.
} 
of income, damage to family life, or major injury to reputation leading to loss of professional or personal opportunities, so the ECtHR held that the case based upon Article 8 was inadmissible.

In sum, Denisov v Ukraine confirms that Article 8 can apply to dismissals for any reason if they cause sufficient damage to a person's ordinary personal life. It does not appear to be necessary any longer to conjoin Article 8 with Article 14 in order to succeed with the consequence-based approach to the interpretation of Article 8. Yet the Grand Chamber declined to assume that unjustified dismissal had caused serious harm to a person's private life, as was done for instance for the dismissal of a judge in Oleksandr Volkov or the security guard in Emel Boyraz. Nor did it confine the question of the seriousness of the harm to the stage of the assessment of the justification of the dismissal by reference to a test of proportionality, as was done for instance in Özpinar v. Turkey, Pay v United Kingdom, and by the minority in Fernández Martinez. Instead, whilst endorsing the consequence-based approach to the interpretation of Article 8(1), the Grand Chamber has insisted that serious adverse effects on personal and professional life have to be proven to bring the case within the consequence-based application of Article 8(1).

\section{The Scope of Protection Against Dismissal}

In the light of those developments in the jurisprudence of the ECtHR, this section analyses what kinds of adverse consequences to private life might suffice for invoking Article 8 in cases of dismissal. These adverse consequences may arise singly or more likely in combination to bring the case within the right to respect for private and family life.

(a) Damage to family life

A dismissal may cause harm in many different ways to family life or what, presumably for reasons of maintaining neutrality between different kinds of personal and domestic relationships, the court prefers to call relationships in the "inner circle". These adverse consequences could arise from material or psychological harm. Material harm usually arises from the loss of an income provided by a job, which 
may create many difficulties for family life such as making it a struggle to feed dependants or to keep a roof over their heads. Unjustified dismissal for misconduct may cause difficulty in obtaining another job, which in turn may have detrimental consequences on family income. Psychological harm resulting from dismissal may consist of psychiatric illness such as depression, which in turn may be harmful to personal relationships by causing, for instance, a breakdown in a marriage or the need for children to be raised by relatives or taken into care.

Whilst it is clear that a dismissal in itself does not count as a material loss that is sufficient to damage family life in a way that engages Article 8, this ground for invoking the protection of this Convention right is potentially broad since damage to family life or relationships in the "inner circle" caused by material hardship could in principle result from any reason given by an employer for dismissal. A severe degree of material harm causing harm to family life could arise, for instance, in cases of economic dismissal or redundancy. In Wandsworth $\mathrm{v}$ Vining, the Court of Appeal acknowledged this possibility and agreed that it would be unwise to lay down a rule that the circumstances of a redundancy can never engage Article $8{ }^{6}{ }^{65}$ In that case, the local authority had closed down its parks police force and dismissed all its constables on the ground of redundancy. The applicants claimed unfair dismissal and a protective award for a failure to consult representatives of the workforce. On the question of whether Article 8 was engaged, the Court of Appeal held that the evidence of damage to family life or personal development was insufficient. They rejected the argument that the relative difficulty of finding new employment for the applicants who were aged 52 and 60 respectively was sufficient in itself, or when combined with evidence of other kinds of damage to personal life, to engage Article $8 .{ }^{66}$ The result might have been different if the applicants had been able to demonstrate particular personal harm resulting from the economic dismissal. For example, in France, in cases of economic dismissal, under section L $1233-5$ of the Code du travail, ${ }^{67}$ an employer is expected to take into account the family sizes of employees, taking note in particular of single parents, and whether or not an employee is likely to experience special difficulties in obtaining a new job, especially those with

\footnotetext{
${ }^{65}$ Wandsworth Borough Council v Vining and Francis [2018] ICR 499 [49].

66 Ibid.

${ }^{67}$ As modified by Ordonnance n²017-1718 du 20 décembre 2017 - art. 1.
} 
disabilities or the elderly; and in cases of assignments to a different location in the same company should seek to avoid upsets in the familial or social life of the employee. ${ }^{68}$ These considerations are apparently designed to take into account the consequence-based factors that might trigger the application of Article 8.

(b) Damage to relationships

Although this second way of describing the harm to private life appears to focus on disruption to personal relationships with others, as in cases concerning interference with communications from work to friends and family, ${ }^{69}$ it is much broader because it includes interference with professional relationships as well. As the court frequently observes,

'It is, after all, in the course of their working lives that the majority of people have a significant opportunity to develop relationships with the outside world' ${ }^{70}$

The ECtHR has added that:

'Restrictions on an individual's professional life may fall within Article 8 where they have repercussions on the manner in which he or she constructs his or her social identity by developing relationships with others'. ${ }^{71}$

Although dismissal from a job does not necessarily sunder contacts with former colleagues or prevent a worker from finding another job through which to form new professional relationships, these consequences may flow from a dismissal in some circumstances. A dismissal that blocks a chosen career path or precludes entry into a profession is likely to prevent a person from establishing and developing relationships with others. The church organist who lost his job because of an extra-marital affair could not work in a church again. As a consequence, he would be excluded from professional communities such as other organists and church choirs, even though these communities had been an

\footnotetext{
${ }^{68}$ J.-E. Ray and J. Rojot, 'Worker Privacy in France', (1995) 17 Comp. Lab. L.J. 61, 63.

${ }^{69}$ Bărbulescu above $\mathrm{n} 39$.

70 Niemitz v Germany, 16 December 1992, \$29, Series A no.251-B

${ }^{71}$ Fernandez Martinez above n 54 [110].
} 
important part of his life hitherto. Similarly, a judge who is unjustly dismissed from office will be excluded from the community of other judges and perhaps the legal profession as a whole. ${ }^{72}$

(c) Damage to personal and professional reputation.

Damage to personal reputation by defamation can fall within the traditional meaning of Article 8 as an aspect of the right to privacy. ${ }^{73}$ The consequence-based approach considers whether the dismissal itself caused harm to a person's reputation or the respect paid to that person, with serious adverse consequences for their personal life or their professional life. For instance, others may shun a worker on hearing of their dismissal on the basis of false allegations about some kind of personal or professional misconduct. A professional who is unjustly dismissed for incompetence or embezzlement may incur severe damage to professional reputation that is likely to prevent that person obtaining other employment in that profession. A manual or an office worker whose employment was unjustly terminated by the employer summarily for unsubstantiated allegations of gross misconduct also risks a possible shadow over his or her work record that may make it far harder to obtain employment again.

The protection of reputation and therefore dignity and respect requires laws that deter false allegations and inferences being drawn about a person's integrity. In Kyriakides $v$ Cyprus, ${ }^{74}$ Article 8 applied where a senior police officer was falsely accused of negligently supervising two police officers accused of torture and was dismissed. The accusation and dismissal infringed upon his psychological integrity and moral integrity and damaged his reputation. Although the Cypriot Supreme Court had held that the dismissal had unjustly violated the applicant's rights, by declining to award any compensation for damage to reputation and moral integrity, it had failed to provide effective protection to the applicant since the false allegations that had effectively ended the policeman's career had not been compensated. It is the consequences of the damage to reputation for an ordinary private life that serve to bring the case within Article 8 and satisfy the condition of seriousness.

\footnotetext{
72 Rainys and Gasparavičius v Lithuania [2005] ECHR 226.

${ }^{73}$ Article 8 does not expressly refer to protection of a person's reputation, though this dimension is present in the right on which it was modelled in Article 12 Universal Declaration of Human Rights

${ }^{74}$ Kyriakides v Cyprus [2008] ECHR 1087.
} 
Given that any dismissal for reasons of misconduct, incompetence, or personal fault may cause some harm to an employee's reputation, the requirement of seriousness in relation to the consequences of an injury to personal reputation has confined the scope of Article 8 significantly. In Denisov $v$ Ukraine the Court explained that 'an attack on a person's reputation must attain a certain level of seriousness and be made in a manner causing prejudice to personal enjoyment of the right to respect for private life. ${ }^{75}$ It rejected the view that dismissal always caused a sufficient damage to a person's reputation. ${ }^{76}$ Applicants are obliged to identify and explain the concrete repercussions on their private life and the nature and extent of their suffering, and to substantiate such allegations by evidence. ${ }^{77}$ In a previous decision concerning the premature dismissal of a Vice-President of the Supreme Court in Hungary, it was assumed by the parties with the approval of the court that the harm to reputation was sufficient even though the applicant had retained his position as a judge. ${ }^{78}$ In Denisov $v$ Ukraine, however, the Grand Chamber carefully examined the evidence that the dismissal from the post of President of the Court, but not from the role of judge, had caused serious harm to the applicant. It concluded that his professional reputation and reputation for integrity had not been damaged sufficiently seriously with adverse effects on his personal and professional life for an issue to be raised under Article $8 .^{79}$

Although the protection for an employee's interest in preserving his or her reputation under Article 8 may be at stake in most cases of disciplinary dismissals, the ECtHR has insisted that, in order to qualify as an interference with Article 8 , the damage to reputation must be undeserved. If the damage to reputation is merited because the charges of misconduct or incompetence are correct, the ECtHR is likely to declare that the adverse consequences resulting from the damage to professional reputation caused by the dismissal do not engage Article $8 .^{80}$

In some cases, however, it is unclear whether the employer's charges are accurate and credible. The allegations of misconduct may be so vague and unspecified, it will be hard to know whether or not

\footnotetext{
${ }^{75}$ Denisov, above n 26, [112].

76 Ibid [113].

77 Gillberg $v$ Sweden [2012] ECHR 569.

78 Erményi v Hungary [2016] ECHR 1029.

79 Denisov, above n 26 [118] - [134].

${ }^{80}$ Gillberg above $\mathrm{n} 77$; the ECtHR might alternatively apply Article 8(2).
} 
they are merited. If so, the damage to reputation may be regarded as unjustified. In other instances, the failure to give the employee any opportunity to hear the detailed allegations and rebut them may in itself make the allegations and damage to reputation unjustified. In Denisov $v$ Ukraine, for instance, the applicant claimed that his dismissal from the post of President of the Court of Appeal for alleged reasons of incompetence had itself damaged his professional reputation. For the purposes of the application of Article 8, however, it did not matter whether or not the allegations of administrative incompetence were true, because the judge's dismissal from his post had taken place without warning when he was on holiday, so he had no chance to rebut them. Similarly, in Özpinar v Turkey, ${ }^{81}$ the female judge who was dismissed for allegations about her private life could claim a consequential damage to her reputation because she had been denied the opportunity to rebut the charges in adversarial proceedings before an independent and impartial supervisory body. The effect of these decisions regarding damage to reputation and its consequences for private life is to read into Article 8 a requirement of procedural fairness that permits the applicant to know the charges and to have an opportunity for a fair hearing to rebut them in order to protect his or her reputation. In the absence of such a trustworthy investigatory process, an applicant does not have to seek to bring the case within Article 6 and the right to a fair trial, for the ECtHR will assume that the charges are unproven and that they caused undeserved adverse effects on an applicant's reputation and private life.

(d) Damage to personal life.

Although the above three headings are those mentioned most frequently by the ECtHR, they appear to form aspects of a broader category, outlined much earlier in Sidabras v Lithuania, that refers to the damage done by an unjustified dismissal to an applicant's personal life or personal development. The core idea is that everyone should be permitted to try to shape their own lives, to be the kind of person that they want to be, even if that independent project leads to unconventional outcomes. Two strands of reasoning can be detected in this broader assessment of damage to private life caused by an unjustified dismissal. One examines the attack on a person's dignity or self-respect. The other looks

\footnotetext{
${ }^{81}$ Above $\mathrm{n} 48$
} 
at the impact of the dismissal on a person's autonomy or ability to choose the way in which they want to live their life.

The dignitarian strand is often stressed in cases where Article 8 is combined with Article 14. In Boyraz v Turkey, for instance, the female security guard had been discriminated against on the ground of her sex. The discrimination was blatant because she had actually been performing the job for three years without any difficulty, despite the employer's claim that women could not do such a dangerous job. The Court assumed, without requiring further evidence, that dismissal on the sole ground of sex had an 'adverse effect on a person's identity, self-perception and self-respect and, as a result, his or her private life.' In other words, the direct discrimination must have damaged her self-esteem or dignity, which in turn must have had an adverse impact on her personal life. Similar reasoning was applied in the case of the person who was dismissed for being HIV positive. This stigmatisation of a HIV-infected person 'was bound to have serious repercussion for his personality rights, the respect owed to him and, ultimately his private life, ${ }^{82}$

The autonomy strand in the idea of damage to personal life is concerned with the adverse consequences for a person's hopes, expectations, and life plans. In this strand of the examination of the adverse consequences of dismissal, it is evident that the ECtHR is drawing on a continental European interpretation of the concept of respect for private life that invokes the idea of 'free development of personality'. For instance, Article 2 of the German Basic Law declares that:

'Every person shall have the right to free development of his personality insofar as he does not violate the rights of others or offend against the constitutional order or the moral law. ${ }^{93}$

As James Q Whitman argues, this constitutional provision aspires 'to allow each individual fully to realize his potential as an individual: to give full expression to his peculiar capacities and powers. ${ }^{84}$ Although the Basic Law is primarily concerned with relations between citizen and state, this right can

\footnotetext{
${ }^{82}$ I.B. above $\mathrm{n} 60$ [72].

${ }^{83}$ Basic Law for the Federal Republic of Germany (Bonn, 8 May 1949) (trans. C. Tomuschat and D. P. Currie).

${ }^{84}$ J. Q Whitman, 'The Two Western Cultures of Privacy: Dignity versus Liberty', (2004) 113 Yale L.J. 1151, 1181.
} 
affect private sector employment relations either in the formulation of legislation, ${ }^{85}$ or by guiding the interpretation of open-textured provisions and fundamental principles in the relevant codes. ${ }^{86}$

It seems that Article 8 ECHR has been used by the ECtHR to include at least many aspects of this right to free development of personality within the Convention. It is this strand in the protection of personal life that comes to the fore in cases where the dismissal has the adverse effect of excluding someone from their chosen career or profession. The refusal to permit a foreign applicant to sit for the Bar examinations in Greece fell within Article 8 because it adversely affected her personal choice as to the way she wished to pursue her professional and private life. ${ }^{87}$ Dismissal from his teaching job effectively prevented Mr Fernández Martinez from pursuing his life choice or vocation of teaching religious education in schools. Similarly, judges who have been unjustly dismissed from office may well experience a feeling of alienation from their own life, for they will now have to start a new career or vocation. Similarly, the manifestation of choices in lifestyle can also be regarded as part of personal development, and dismissal or the threat of dismissal can damage the opportunity to manifest such choices. Although the judge in Özpinar v. Turkey denied that she even owned a miniskirt, if she had worn one in her private time and had been dismissed for that personal choice, the dismissal or threat of dismissal could be regarded as an interference with Article 8 if it was calculated to force her to adopt a different, more conservative, lifestyle.

\section{Limits to the Protection of the Right}

As we have seen, the concept of privacy in Article 8, interpreted as involving protection of the enjoyment of personal life, is a vital expression of the values of dignity and the protection of autonomy or a positive liberty to develop one's own life. The abstract idea of free development of personality

\footnotetext{
85 The German Works Council Act 1972, which establishes the basic legal framework of co-determination in the private sector, prescribes in Section 75 (2): 'The employer and the works council shall safeguard and promote the untrammelled development of the personality of the employees of the establishment. They shall promote the independence and personal initiative of the employees and working groups.

${ }^{86}$ M. Weiss and B. Geck, 'Worker Privacy in Germany', (1995) 17 Comp. Lab. L.J. 75.

${ }^{87}$ Bigaeva v Greece [2011] ECHR 2164.
} 
thus creates a link between, on the one hand, the values of dignity and autonomy that were presented in section 2 above as the best justification for a fundamental right to protection against unjustified dismissal and, on the other hand, the values contained within the European concept of privacy under Article 8 of the Convention. It makes good sense to invoke Article 8 as the basis of a general protection against unjustified dismissal, for key values that inform the scope of that Convention right also provide the main reasons why national laws should have adequate protection against unjustified dismissal. From this perspective, the nub of the human right against unjustified dismissal is not so much concerned with regulating the exercise of managerial discretion with regard to the grounds and procedures for lawful termination of employment, but is rather designed to ensure adequate protection for a person's autonomy and dignity with respect to the ways that they can be damaged by the consequences of unjustified dismissals.

Under the ECHR, the contracting states must ensure that they provide sufficient protections against unjustified dismissal to achieve compliance with Article 8. To appreciate properly what this obligation requires, three important limits on Article 8's requirements for protection against unjustified dismissal under national law need to be highlighted.

(a) Significant disadvantage

In the consequence-based approach to Article 8, the ECtHR has often mentioned that the adverse effects of dismissal should be significant to a person's life and that criterion has been emphasised in Denisov $v$ Ukraine. In addition, since 2010, one of the general criteria for the admissibility of a case before the ECtHR is that the applicant should have suffered a 'significant disadvantage' from the violation of his or her Convention rights. ${ }^{88}$ This requirement provides the court with a filter by which it can decline to hear cases where it forms the opinion that the detriment suffered by the applicant from the dismissal

\footnotetext{
${ }^{88} \operatorname{Art} 35(3)$ (b) [The Court shall declare an application inadmissible] 'if the applicant has not suffered a significant disadvantage, unless respect for human rights as defined in the Convention and the Protocols thereto requires an examination of the application on the merits and provided that no case may be rejected on this ground which has not been duly considered by a domestic tribunal'. (entered into force 1 June 2010). Cf D. Shelton, 'Significantly Disadvantaged? Shrinking Access to the European Court of Human Rights', (2016) 16 Human Rights Law Review 303.
} 
did not amount to a significant disadvantage. It was used in Denisovv Ukraine to declare the application under Article 8 not just unsuccessful, but inadmissible. The ECtHR now also insists that the applicant's evidence of harm to family and personal life should have been put before the national courts if it is to be considered as evidence of a breach of Article 8 by those courts. If necessary, as in Denisov $v$ Ukraine, the ECtHR will engage in a detailed assessment of the evidence of significant disadvantage provided by the applicant in order to decide whether or not to admit a case to the merits stage of a hearing. After a detailed investigation of all the proven consequences of the dismissal from the office of President of the Court of Appeal, the ECtHR 'concluded that the dismissal had limited negative effects on the applicant's private life and did not cross the threshold of seriousness or significant disadvantage for an issue to be raised under Article 8 of the Convention' ${ }^{99}$

The Grand Chamber offered guidance as to how courts should assess the severity of alleged violations of Convention rights.

'An applicant's suffering is to be assessed by comparing his or her life before and after the measure in question. The Court further considers that in determining the seriousness of the consequences in employment-related cases it is appropriate to assess the subjective perceptions claimed by the applicant against the background of the objective circumstances existing in the particular case. This analysis would have to cover both the material and non-material impact of the alleged measure. ${ }^{90}$

Although a substantial proportion of dismissals may not satisfy this requirement of significant disadvantage in order to be admitted before the ECtHR, it is worth noting that there are two kinds of cases involving dismissals where the test of significant disadvantage seems likely to be satisfied without difficulty. The first group concerns those cases where the dismissal interferes with an individual's right to pursue a chosen profession or vocation. For instance, cases concerning judges dismissed from office have easily passed this test of significant disadvantage because there was a permanent interference with their right to work at their chosen career. A second group of cases where the test of significant

\footnotetext{
${ }^{89}$ Denisov, above n 26, [133]. The Court's decision may also have been influenced by the point that the applicant was due to retire in any event in 2013, which he did, so the negative effects of the dismissal would have been fairly short-lived.

${ }^{90}$ Ibid [117].
} 
disadvantage is highly likely to be met is where there is a violation of a Convention right other than the extended meaning of the consequence-based approach to Article $8 .^{91}$ For instance, it seems likely that dismissal of an employee because he is HIV-positive would count as significant disadvantage because of the attack on equal respect contrary to Article 14 even if, as happened in $I B v$ Greece, the employee suffered no material harm from the dismissal.

(b) Justification and the Margin of Appreciation

To ensure conformity with the ECHR, a national court handling a claim for unjustified dismissal must follow the series of questions posed by the Convention. The court or tribunal must consider first whether a particular Convention right is applicable in the circumstances, taking into account the interpretations placed on those rights by the ECtHR. If a Convention right is engaged, it must then consider whether interference with it by the employer may be justified under any exceptions or qualifications in the formulation of the relevant Convention right. As previously discussed, Article $8(2)$ permits the justification of interferences with the right to privacy on the ground that they are necessary to protect the rights of others. These include the rights and freedoms of public and private employers. Their protected interests may include such matters as peaceful enjoyment of their property rights and the protection of their reputation, confidential information, and other business interests. In many of the hardest cases, therefore, a court has to balance the interest of the employee in protection against harm to his or her personal life against the interest of the employer in protecting its interests by dismissing the employee. In Fernández Martinez v Spain, as we noted above, the issue boiled down to a weighing of the interest of the applicant to continue to enjoy his career as a religious education teacher against the importance that his employer placed on only appointing persons approved under the rules and doctrines of the Catholic Church.

In making that assessment of the proportionality of the dismissal, a national court may be accorded by the ECtHR a margin of appreciation. Provided that the national court asks these questions correctly,

91 Giusti v Italy, App No 13175/03, 18 October 2011. 
taking into account all the relevant considerations, its decision on the facts may be regarded by the ECtHR as being within the state's margin of appreciation, even though it is not a decision that the ECtHR would have reached. ${ }^{92}$ In this context, however, the margin of appreciation accorded to judgments of national courts' assessments is not great. Recall, for instance, the decision in Schüth v Germany that the national court had attributed too much weight to the Church's desire to uphold its doctrines in comparison to the harm caused by termination of the career of the organist. ${ }^{93}$ Similarly, as in $\ddot{O}_{\text {zpinar }} v$ Turkey, ${ }^{94}$ the margin of appreciation will be narrow where there is poor reasoning on the part of the national court. This is likely to prompt the ECtHR to intervene and find a failure to protect a Convention right adequately because the details of the case were not properly investigated. A powerful dissenting minority of eight judges of the Grand Chamber in Fernández Martinez v Spain applied a strict scrutiny to the employer's reasons for dismissal and the balancing process carried out by the Spanish constitutional court and concluded that, contrary to the views of the majority and the national court, the dismissal was not proportionate and necessary in accordance with Article $8(2){ }^{95}$ Although there is a narrow margin of appreciation when the national court asks the right questions and reaches a reasonable balance of the competing interests, the review conducted by the ECtHR is intense compared to, for example, their review of national laws that interfere with the right to strike. ${ }^{96}$

(c) Reasons for Dismissal and Disciplinary Procedures

Although the scope of control over unjustified dismissals is extensive under the ECHR, it differs somewhat from the approach established in the ILO Convention 158 on Termination of Employment 1982, and its partial replication in the Revised European Social Charter 1996 Article 24. The question

\footnotetext{
92 Eg Palomo Sanchez v Spain [2011] ECHR 1319; Obst v Germany App no 425/03 (23 September 2010); cf F. Hendricxx and A Van Bever, 'Article 8 ECHR: Judicial Patterns of Employment Privacy Protection' in F. Dorssemont, K. Lörcher and I Schömann (eds), The European Convention on Human Rights and The Employment Relation (Oxford: Hart Publishing, 2013) 183, 195.

93 Schüth above n 59.

94 Özpinar above $\mathrm{n} 48$.

${ }^{95}$ Fernandez Martinez, above n 54 [32].

${ }^{96}$ National Union of Rail, Maritime and Transport Workers above $\mathrm{n} 27$.
} 
to be considered here is how far the protection against unjustified dismissal provided by the ECHR falls short of the demanding standards of Article 24 and the ILO Convention.

Both Article 24 and the ILO Convention focus on the same requirement for an employer to give reasons for dismissal and for those reasons to be valid reasons connected with the capacity or conduct of the employee or the organisational requirements of the business. ${ }^{97}$ Particular reasons for dismissal such as membership of a trade union, discrimination on grounds of race and sex and other protected characteristics, the filing of a legal complaint, and temporary absence through sickness are forbidden as invalid. ${ }^{98}$ The ILO Convention also explicitly requires the employer to follow a fair procedure prior to termination of employment. The reason for focussing on the employer's reason for dismissal in these international standards is in part to make it clear that laws that merely require an employer to pay compensation on termination of employment do not comply with the international standard, because they fail to investigate the justice of the dismissal and vindicate employees in cases of unfairness. A further reason for detailed assessment of the reasons for dismissal is to try to ensure, as explained in the Recommendation that accompanies the ILO Convention as an aid to its interpretation, ${ }^{99}$ that only reasons that serve a legitimate purpose and are proportionate are likely to count as valid reasons for dismissal. The question to be considered here is whether the different focus that has emerged under the ECHR entails a more restrictive coverage of its protection against unjustified dismissal than these international labour standards and social rights.

With respect to the assessment of the employer's reasons for dismissal, it is evident that the consequence-based approach to Article 8 may not directly assess an employer's reasons for dismissal. Nevertheless, it is clear that many of the grounds for dismissal that would be regarded as invalid under the ILO Convention or the Revised European Social Charter would also be rejected by the ECtHR as unjustified interferences with Convention rights such as the protection for trade union membership and activities under Article 11. Furthermore, as illustrated by Sidabras and Emel Boyraz, Article 14 ECHR provides a fertile ground for challenging discriminatory and arbitrary grounds for dismissal. Dismissal

\footnotetext{
97 ILO Convention 1982, No 158 Article 4; ESC (revised) Article 24 (a).

98 ILO Convention 1982, Articles 5 and 6; ESC (revised) Appendix Part II, Article 24, para 3.

${ }^{99} \mathrm{R} 166$, above n 10.
} 
by an employer without giving any reasons at all could possibly be challenged in cases with serious adverse impact on private life under the consequence-based approach to article 8 . It is more likely, however, that the ECtHR would be receptive to an application under Article 6. A failure to give reasons for a dismissal makes it hard for an employee to challenge a dismissal in court, which blocks an applicant's effective access to a court to enforce his or her civil rights. ${ }^{100}$

The ILO Recommendation that adds additional elements to the Convention indicates that dismissal can only be justified if the reasons were both valid and sufficient. ${ }^{101}$ Dismissal on potentially valid grounds such as misconduct or lack of capacity to perform the job should be open to assessment on the issue of whether the misconduct or lack of capacity, if proven, was sufficiently serious to merit dismissal or whether some other disciplinary or managerial action would have been more appropriate in the circumstances. As is well known, in the UK law of unfair dismissal, owing to the 'range of reasonable responses' test of fairness, ${ }^{102}$ such a fine-grained assessment of the proportionality of a dismissal tends to be avoided by employment tribunals. As illustrated in Fernández Martinez v Spain, however, the ECtHR does sometime engage in such a detailed measurement of the balance of interests in its application of the test of proportionality for justifications for interferences with Convention rights. In cases concerning injury to reputation leading to adverse consequences for private life, some assessment of whether the grounds given to the applicant for dismissal were valid will be necessary in order to avoid the conclusion that the dismissal was just, but even if they are invalid or inadequate to justify a dismissal, Article 8 may not afford protection if, as in Denisov, the adverse consequences are not severe. In general, however, the consequence-based interpretation of Article 8(1) avoids detailed specification of the kinds of reasons that should be regarded as valid and sufficient for a just dismissal.

\footnotetext{
100 K.M.C. above n 13.

101 R166, above n 10, '7. The employment of a worker should not be terminated for misconduct of a kind that under national law or practice would justify termination only if repeated on one or more occasions, unless the employer has given the worker appropriate written warning. 8. The employment of a worker should not be terminated for unsatisfactory performance, unless the employer has given the worker appropriate instructions and written warning and the worker continues to perform his duties unsatisfactorily after a reasonable period of time for improvement has elapsed.'

102 British Leyland UK Ltd v Swift [1981] IRLR 91 (CA); Foley v Post Office, HSBC Bank plc v Madden [2000] ICR 1283, [2000] IRLR 827.
} 
The ILO Convention (but not the revised ESC) emphasises the importance of the employer following a fair procedure prior to a dismissal. ${ }^{103}$ The ECtHR has not developed an equivalent requirement for employers to carry out fair disciplinary procedures under Article $6 .{ }^{104}$ Like the revised ESC, the requirement has so far been confined to access to a court or impartial tribunal to determine whether any civil right has been breached. Nevertheless, if an employer seeks to justify a dismissal by reference to alleged misconduct of the employee, a fair process is required in effect under Article 8. In the absence of such a fair disciplinary process, either the alleged misconduct would probably have little evidence to support it and justify the dismissal, or the employee would not have had a proper opportunity to rebut the allegations. Subject to the issue of significant disadvantage, as in Özpinar v Turkey, either failure of a fair procedure should support the application of a consequence-based interpretation of Article 8(1) to the facts of the case and undermine any attempt at justification under Article 8(2).

On this issue of the restricted or weaker protection against unjustified dismissal under the ECHR in comparison with the ILO Convention and Article 24, one last issue needs to be considered. In many other contexts concerning labour rights, the ECtHR has used as an aid to an interpretation of Convention rights the standards set by the ESC and ILO Conventions, as they have been interpreted by the relevant committee of experts. This 'integrated approach' to interpretation was applied, for instance, in Wilson and Palmer $v U K^{105}$ to justify an interpretation of freedom of association in some circumstances to include a right to collective bargaining, and also in Sidabras and Džiautas v Lithuania to broaden the meaning of Article 8 by reference to the right to work. ${ }^{106}$ What is striking in the above discussion of decisions of the ECtHR with regard to dismissals is that, with rare exceptions, there is no reference to or discussion of ESC Article 24 or the ILO Convention. ${ }^{107}$ The main exception occurred in K.M.C. $v$

\footnotetext{
103 C-158, Article 7; R166, paragraphs 7-13.

104 A Sanders, 'A “Right” to Legal Representation (in the workplace) During Disciplinary Proceedings?' (2010) 39 ILJ 166.

105 Wilson and Palmer and the National Union of Journalists $v$ UK [2002] IRLR 568.

106 Mantouvalou, above $\mathrm{n} 44$.

107 Both are mentioned in Heinisch above n 24, [38]-[39], a case concerned with whistle-blowing, but after noting that Germany had ratified neither, the ECtHR did not rely upon the prohibition of the invalid reason for dismissal in response to the employee having commenced legal proceedings as the justification for a finding of unjustified interference with freedom of expression.
} 
Hungary, ${ }^{108}$ where the government dismissed a civil servant without giving any reasons, as was permitted at that time under Hungarian law. Having concluded that there was no ground for contesting fairness of the dismissal before the national courts in the absence of any reasons given by the employer for the dismissal, the applicant succeeded in bringing a claim for violation of Article 6 ECHR on the ground that she had been denied access to a court. That conclusion was supported by reference to ESC Article 24, which expressly requires judicial oversight of the justice of a dismissal.

In a concurring opinion, however, Judge Pinto de Albuquerque suggested that Article 6 should be interpreted more broadly by reference to both Article 24 ESC and Article 4 of the ILO Convention, so that it would require employers not only to provide reasons for a dismissal, but also to put forward the approved kinds of valid reasons such as misconduct, lack of capability, and the economic needs of the business. Claiming that the requirement to give valid reasons for dismissal was part of a European consensus on protection in cases of termination of employment, he maintained that this requirement of Article 6 applied even to those contracting states such as Hungary (and the UK) which had not undertaken the obligations under article 24 ESC. Summing up, the learned judge stated (using underlining for emphasis):

'the right to protection in the event of termination of employment has a minimum content in European human rights law, consisting of four core requirements: a formal written notice of termination of employment given to the employee, a pre-termination opportunity to respond given to the employee, a valid reason for termination, and an appeal to an independent body.' In order to provide a legal basis for a requirement that employers should follow a fair disciplinary procedure, it is possible that the ECtHR will adopt this expansive view of the requirements of Article 6 ECHR in the future.

This brief comparison between a right to protection against unjustified dismissal under the ECHR and that established under Article 24 of the revised European Social Charter and the standard endorsed in ILO Convention 158 suggests that the superficial differences in appearance may not matter so much in practice. Although it is true that the focus of the ILO Convention and Article 24 is on the reasons

108 Above n 13. 
given for the dismissal whereas under the ECHR it the enquiry is partly concerned with reasons but also with the consequences to private life, a careful assessment of the adequacy of the reasons for the dismissal is likely to arise under both approaches, though such as assessment may only occur under the ECHR at the stage of justification.

\section{Conclusion}

This article has tracked the emergence of a right to protection from unjustified dismissal through an extended interpretation of Article 8 ECHR. The Convention right provides protection for dignity and personal autonomy (or personal development) by focussing on the adverse impact on private life of an unjustified dismissal. It has been suggested that this focus on dignity and autonomy is appropriate because ultimately the best justification for laws that protect workers against unjustified dismissal also points to the need to protect dignity and autonomy in accordance with the maxim that 'labour is not a commodity'. The emergence of a human right to protection against unjustified dismissal requires contracting states under the ECHR to ensure that their national laws provide legal protections for workers that conform to the Convention rights.

The consequence-based interpretation of Article 8 has considerably broadened the scope of protection under the ECHR. Whereas in the past a dismissed employee had to bring the case within the substantive meaning of one of the Convention rights in accordance with a reason-based approach to dismissals, such as freedom to manifest a religion or freedom of association, the consequence-based approach can include any kind of reason for dismissal, provided that the dismissal has had a severe adverse impact on a person's ordinary personal life.

What differences to the position of workers might happen with the advent of an international protection of a right to protection against unjustified dismissal? Most contracting states under the ECHR already provide through laws and collective agreements a significant degree of protection against unjustified dismissal, so one should not expect radical changes to arise from a recognition of a human

right. Nevertheless, the presence of a general right may provide opportunities to challenge how national courts balance the interests of employers against those of their employees in deciding the question of 
justification. It should be harder for courts to defer to the interests of employers if a fundamental right of workers is being weighed in the balance of fairness or reasonableness. For instance, on this interpretation of Article 8, dismissals should not be held by a court or tribunal be 'harsh but fair', ${ }^{109}$ because the harshness of the consequences for personal life of a poorly justified dismissal requires protection from unjustified dismissal under the Convention. Furthermore, a general right to protection against unjustified dismissal can provide the springboard for challenging various kinds of exclusions and obstacles to the vindication of the right. For example, it must be questioned whether substantial sections of the workforce should be excluded from the protection from unjustified dismissal on such grounds as the temporary nature of their employment or that under the terms of their they purport to work for their employer as a self-employed, though dependent contractor, or some other unprotected status. The existence of a human right to protection against unjustified dismissal, when combined with the right to a fair trial under article 6 ECHR, should also provide a legal basis for challenging national legislation that effectively prevents workers' claims against dismissal, whether these obstructions be created by excessive court fees, the absence of available courts and judges, or abbreviated limitation periods. As the ECHR recognises, the proper vindication of a human right may require just satisfaction' by the award of substantial compensation, including in appropriate cases an award for injury to feelings. The existence of a human right may therefore provide a basis for challenging restrictions on the amount of and grounds for compensation under the law of unfair dismissal. Whilst these potential legal ramifications of a general fundamental right to protection against unjustified dismissal are inevitably speculative, what seems certain is that the importance of this right to the protection of the dignity and autonomy of workers must lead us to welcome the arrival at last of this fundamental labour right as a human right.

${ }^{109}$ Collins, above n 29, 7 . 